\title{
CHEMICAL CONSTITUENTS FROM THE STEM BARK OF ZANTHOXYLUM SCANDENS
}

\author{
MING-JEN CHENG ${ }^{1,2,3}$ CHUAN-FANG LIN ${ }^{1,3}$ HSUN-SHUO CHANG ${ }^{1}$ IH-SHENG CHEN ${ }^{{ }^{*}}$ \\ ${ }^{1}$ Graduate Institute of Natural Products, College of Pharmacy, Kaohsiung Medical University, Kaohsiung, Taiwan 807, Republic of China. \\ ${ }^{2}$ M.-J. C. and C.-F. L. contributed equally to the work in this paper. \\ Bioresource Collection and Research Center (BCRC), Food Industry Research and Development Institute (FIRDI), \\ Hsinchu, Taiwan 300, Republic of China. \\ (Received: March 7, 2008 - Accepted: June 5, 2008)
}

\begin{abstract}
One new dioxoaporphine alkaloid, zanthodione (1), together with nineteen known compounds have been isolated from the stem bark of Zanthoxylum scandens. The structures of these compounds were determined by means of spectral analyses. Except for zanthodione (1), methyl vanillate, vanillic acid, and 2(4'-hydroxyphenyl)ethyl hexacosanoate, all of the other 16 compounds, as same constituents found in Z. ailanthoides, which were evaluated for inhibition of HIV replication in $\mathrm{H} 9$ lymphocyte cells in our previous report in Bioorg. Med. Chem.. The reported decarine, $\gamma$-fagarine, and (+)-platydesmine were the most potent anti-HIV constituents, with $\mathrm{EC}_{50}$ values ranging from 0.1 to $1.34 \mu \mathrm{g} / \mathrm{mL}$ and $\mathrm{TI}$ (Therapeutic Index) values from 74 to 231 , also isolated from the stem bark of this plant.
\end{abstract}

Keywords: Zanthoxylum scandens, Rutaceae, stem bark; dioxoaporphine; anti-HIV activity.

\section{INTRODUCTION}

Zanthoxylum scandens Blume (Zanthoxylum cuspidatum Champ. ex Benth.) (Rutaceae) is a woody climbing vine distributed in India, China, the Ryukyus, Sumatra, Java, and Borneo, growing at low altitudes throughout Taiwan. ${ }^{1}$ The root and stem with leaves of this plant have been used as folk medicine to treat abdominal pain, toothache, rheumatism, and traumatic injury. ${ }^{2}$ The chemical constituents of this plant's (leaves, ${ }^{3}$ root bark, ${ }^{3}$ wood, ${ }^{4,5}$ root, ${ }^{6}$ and bark,,${ }^{5,7,8}$ ) such as flavonoids, benzo[c]phenanthridines, phenylpropanoids, coumarins, quinolines, $N$-isobutylamides, lignans, triterpenoids, indolopyridoquinazoline $\mathrm{s}$, and others have been reported in the past. So far, twenty-eight constituents have been obtained from this plant. Nonetheless it may be assumed that minor constituents still remain to be found.

In our continuing studies on the anti-HIV constituents of Formosan plants, over 1000 species have been screened for in vitro anti-HIV activity to date, and Z. scandens has been found to be one of the active species with a therapeutic index (TI, TI value $=$ concentration that inhibits uninfected $\mathrm{H} 9$ cell growth by $50 \%$ /concentration that inhibits viral replications by $50 \%$ ) of $>200$, as in the case of the root bark of Z. ailanthoides ${ }^{9}$ and the root wood of Z. integrifoliolum..$^{10}$ Careful re-examination of the stem bark of $Z$. scandens led to the isolation of the new compound, zanthodione (1), along with 19 reported known compounds, 10 of which had not been described previously as constituents of this plant. The anti-HIV principles of $Z$. ailanthoides already certified to be decarine, $\gamma$-fagarine, and (+)-platydesmine, with TI values $>226$, $>231$, and $>74.4,{ }^{9}$ respectively. These three bioactive compounds also isolated in this study. In this article, structural elucidation of $\mathbf{1}$ and the SAR (structure and activity relationship) on the anti-HIV activity of some of the isolates compounds are discussed herein.

\section{EXPERIMENTAL}

\section{General Experimental Procedures}

Melting points were determined with a YANACO micro-melting point apparatus and were uncorrected. IR spectra were taken on a Hitachi 26030 spectrophotometer. UV spectra were obtained on a JASCO UV-240 spectrophotometer. EIMS spectra were recorded on a VG Biotech Quattro 5022 spectrometer. HREIMS were recorded on a JEOL JMX-HX 110 mass spectrometer. ${ }^{1} \mathrm{H}$ NMR and ${ }^{13} \mathrm{C}$ NMR spectra were measured on a Varian Gemini 200, Varian Unity Plus 400, and Varian Unity Inova 500 and 600 spectrometers, and are given in parts per million $(\delta)$ downfield from internal TMS. Silica gel 60 (Merck 70-230 mesh, 230-400 mesh) was used for column chromatography, and Si gel $60 \mathrm{~F}_{254}$ (Merck) for TLC.

\section{Plant Material}

The stem bark of $Z$. scandens was collected in Mutan, Pintung County, Taiwan, $22^{\circ} 17^{\prime} \mathrm{N}, 120^{\circ} 81^{\prime} \mathrm{E}$ in July, 2003. A voucher specimen (Chen 5528) was deposited in the Herbarium of the College of Pharmacy, Kaohsiung Medical University, Kaohsiung, Taiwan, R.O.C.

\section{Extraction and separation of compounds}

The stem bark $(7.6 \mathrm{~kg})$ was sliced into chips, extracted with cold $\mathrm{MeOH}$ and concentrated under reduced pressure. The methanolic extract $(380 \mathrm{~g})$ was partitioned between $\mathrm{CHCl}_{3}$ and $\mathrm{H}_{2} \mathrm{O}(1: 1)$, to afford $\mathrm{CHCl}_{3}$ (fraction $\mathrm{A}$, $90 \mathrm{~g}$ ) and $\mathrm{H}_{2} \mathrm{O}$-soluble fractions, and an insoluble precipitate (fraction $\mathrm{B}, 5$ g). The $\mathrm{H}_{2} \mathrm{O}$ solution was extracted with $n-\mathrm{BuOH}$. The $n$ - $\mathrm{BuOH}$ extract was concentrated in vacuo to give a residue (fraction $\mathrm{C}, 14 \mathrm{~g}$ ). The detail separation and fractionation of fractions $\mathrm{A}, \mathrm{B}$, and $\mathrm{C}$ were illustrated by the following three schemes.

\section{Spectroscopic data}

Zanthodione (1): orange needles; mp. $254-256{ }^{\circ} \mathrm{C}$; UV (MeOH) $\lambda_{\text {max }}(\log$ ع) 239 (sh) (4.49), 249 (4.51), 392 (sh) (3.58), 408 (4.51), 428 (3.58) nm; IR $(\mathrm{KBr}) \mathrm{v}_{\max } 3389(\mathrm{OH}) ; 1660,1646(\mathrm{C}=\mathrm{O}) ; 1601,1460$ (aromatic ring $\mathrm{C}=\mathrm{C}$ ); $1040,940\left(\mathrm{OCH}_{2} \mathrm{O}\right) \mathrm{cm}^{-1} ;{ }^{1} \mathrm{H} \mathrm{NMR}\left(\mathrm{CDCl}_{3}, 600 \mathrm{MHz}\right) \delta 6.40\left(2 \mathrm{H}, \mathrm{s}, \mathrm{OCH}_{2} \mathrm{O}\right)$, $7.73(1 \mathrm{H}$, br ddd, $J=8.4,7.2,1.8 \mathrm{~Hz}, \mathrm{H}-10), 7.77(1 \mathrm{H}, \mathrm{dt}, J=7.2,1.2 \mathrm{~Hz}$, $\mathrm{H}-9), 8.04(1 \mathrm{H}, \mathrm{s}, \mathrm{H}-7), 8.26\left(1 \mathrm{H}, \mathrm{s}, \mathrm{NH}\right.$ exchangeable with $\left.\mathrm{D}_{2} \mathrm{O}\right), 8.29(1 \mathrm{H}$, dd, $J=7.2,1.8 \mathrm{~Hz}, \mathrm{H}-8), 9.26(1 \mathrm{H}, \mathrm{d}, J=8.4 \mathrm{~Hz}, \mathrm{H}-11), 11.98(1 \mathrm{H}, \mathrm{s}, \mathrm{OH}$ exchangeable with $\mathrm{D}_{2} \mathrm{O}$ ); EIMS $\mathrm{m} / \mathrm{z} 307[\mathrm{M}]^{+}(90)$; HRESIMS $\mathrm{m} / \mathrm{z} 307.1481$ (calcd for $\mathrm{C}_{17} \mathrm{H}_{9} \mathrm{NO}_{5}, 307.1480$ ).

\section{RESULTS AND DISCUSSION}

Zanthodione (1) was obtained as orange needles. Its molecular formula $\mathrm{C}_{17} \mathrm{H}_{9} \mathrm{NO}_{5}$ was established by EIMS ([M] $]^{+}, \mathrm{m} / z$ 307) and HRESIMS. The UV spectrum showed absorption maxima at 239 (sh), 240, 249, 392 (sh), 408, 428 $\mathrm{nm}$, that indicated the presence of a 4,5-dioxoaporphine skeleton. ${ }^{11,12}$ Its IR spectrum indicated the presence of $\mathrm{OH} / \mathrm{NH}\left(3000 \sim 3389 \mathrm{~cm}^{-1}\right)$, two aryl ketone $\mathrm{C}=\mathrm{O}\left(1660,1646 \mathrm{~cm}^{-1}\right)$, one methylenedioxy $\left(1040,940 \mathrm{~cm}^{-1}\right)$ and a sixmembered lactam $\left(1587 \mathrm{~cm}^{-1}\right)$ functionalities. The ${ }^{1} \mathrm{H}$ NMR spectrum revealed five aromatic protons, two $\mathrm{D}_{2} \mathrm{O}$ exchangeable singlets of a H-bonded phenolic hydroxyl $[\delta 11.98(1 \mathrm{H}, \mathrm{s})]$, and an amidocarbonyl proton at $\delta 8.26(1 \mathrm{H}, \mathrm{s})$, and a methylenedioxy group at $\delta 6.40(2 \mathrm{H}, \mathrm{s})$. Five aromatic protons of the spectrum closely resembled those of other 7,8,9,10,11-unsubstituted dioxoaporphine. ${ }^{11}$, ${ }^{12}$ Therefore, the methylenedioxy group had to be on ring A. The singlet at $\delta$ $8.04(1 \mathrm{H}, \mathrm{s})$ was ascribed to $\mathrm{H}-7$ while $\mathrm{H}-8, \mathrm{H}-9, \mathrm{H}-10$ and $\mathrm{H}-11$ appeared as a complex ABCX coupling system. In agreement with the spectra of other C11-unsubstituted aporphines, dehydro- and oxoaporphines, the most downfield doublet $[\delta 9.26(1 \mathrm{H}, \mathrm{s})]$ was characteristic of $\mathrm{H}-11$, the $2 \mathrm{H}[\delta 7.73(1 \mathrm{H}$, ddd, $J=8.4,7.2,1.8 \mathrm{~Hz}), 7.77(1 \mathrm{H}, \mathrm{dt}, J=7.2,1.2 \mathrm{~Hz})]$ were assigned to $\mathrm{H}-10$, 9 , and another proton at $\delta 8.29(1 \mathrm{H}, \mathrm{dd}, J=7.2,1.8 \mathrm{~Hz})$ was due to $\mathrm{H}-8$. The correlations of $\mathrm{H}-7 / \mathrm{NH}$, and $\mathrm{H}-8 / \mathrm{H}-7,9$ were also disclosed in the NOESY experiment (Fig. 1) and further supported the position of above assignments. By means of ${ }^{1} \mathrm{H}-\mathrm{NMR},{ }^{1} \mathrm{H},{ }^{1} \mathrm{H}-\mathrm{COSY}$, and NOESY (Fig. 1) data, the structure of zanthodione was shown to be 4-hydroxy-7H-benzo $[g][1,3]$ dioxolo[4',5';4,5 ]benzo[1,2,3-de]quinoline-5,6-dione (1).

Dioxoaporphine alkaloids are unusual in nature and have been isolated from Piper (Piperaceae), ${ }^{13}$ Aristolochia (Aristolochiaceae), ${ }^{14}$ Houttuynia 


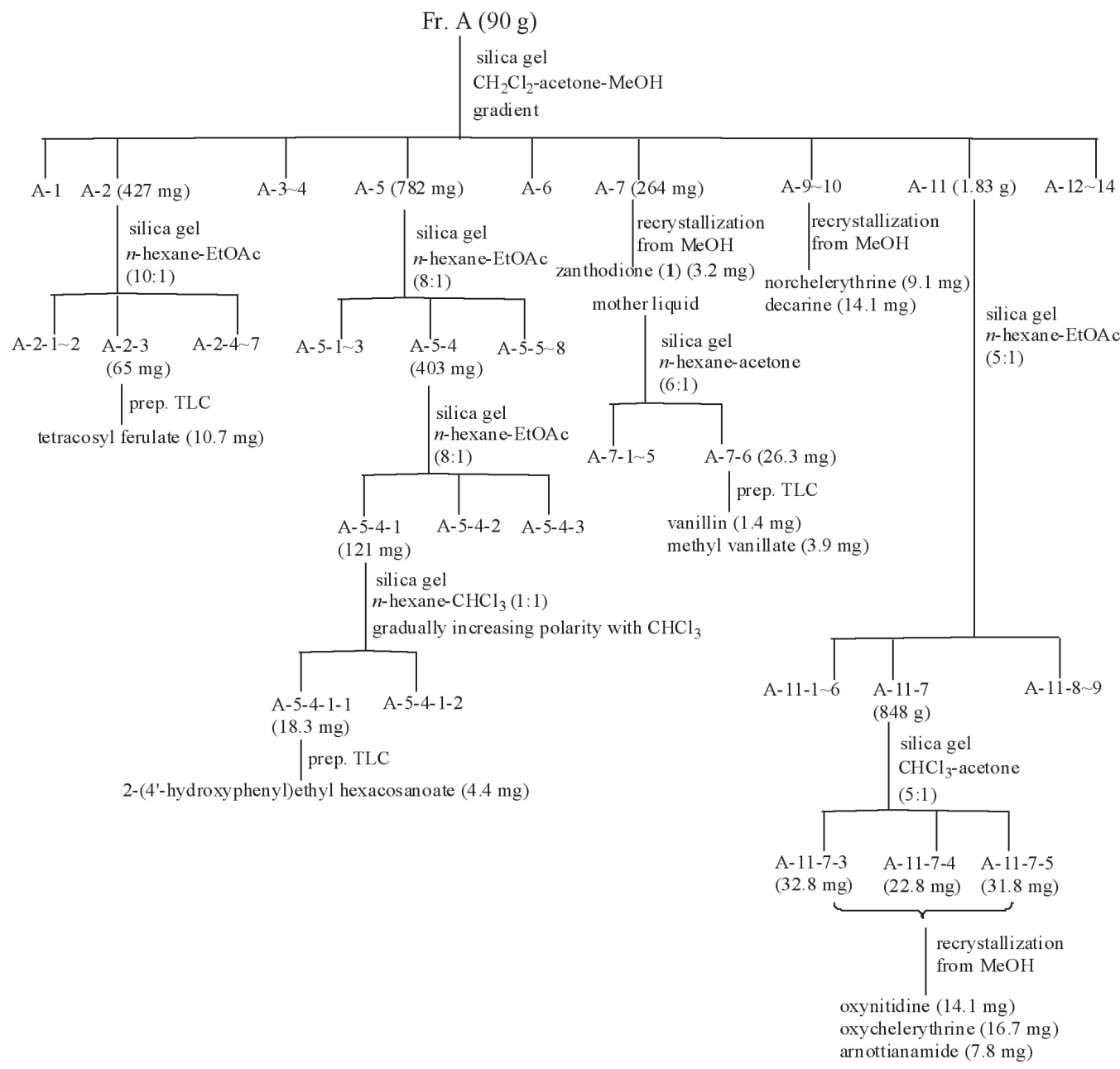

Fr. B (5 g)

silica gel

$\mathrm{CH}_{2} \mathrm{Cl}_{2}-\mathrm{MeOH}$

gradient

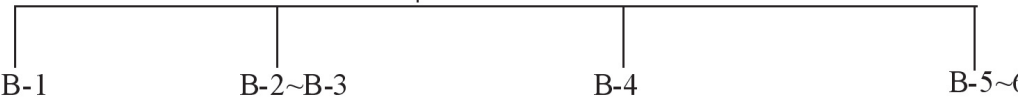

B-1

$$
\text { (1.5 g) }
$$

silica gel

$\mathrm{CH}_{2} \mathrm{Cl}_{2}$-EtOAc (20:1)

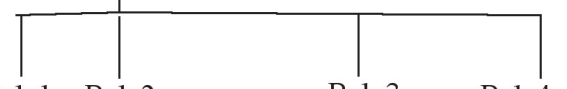

B-1-1 B-1-2

(125 mg)

prep. TLC

a mixture of $\beta$-sitosterol

and stigm asterol $(11.2 \mathrm{mg})$

$(+)$-ses am in $(1.5 \mathrm{mg})$

$$
\begin{aligned}
& \text { B-1-3 } \\
& \text { (75 mg) } \\
& \text { prep. TLC } \\
& \text { lupeol }(4.3 \mathrm{mg} \text { ) }
\end{aligned}
$$

B-1-4 6 crystals

unknown crude mother liquid

after recrystallization

from $\mathrm{MeOH}$

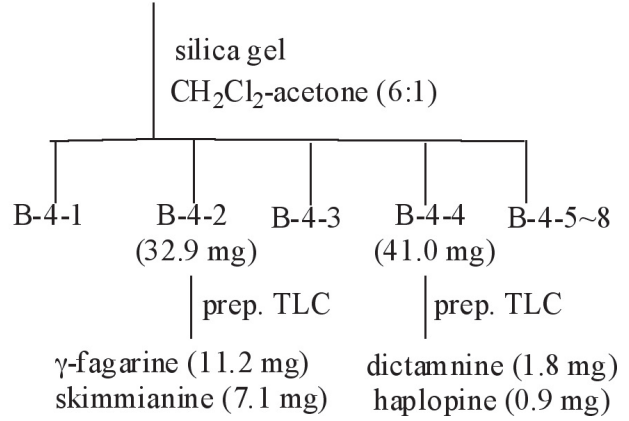




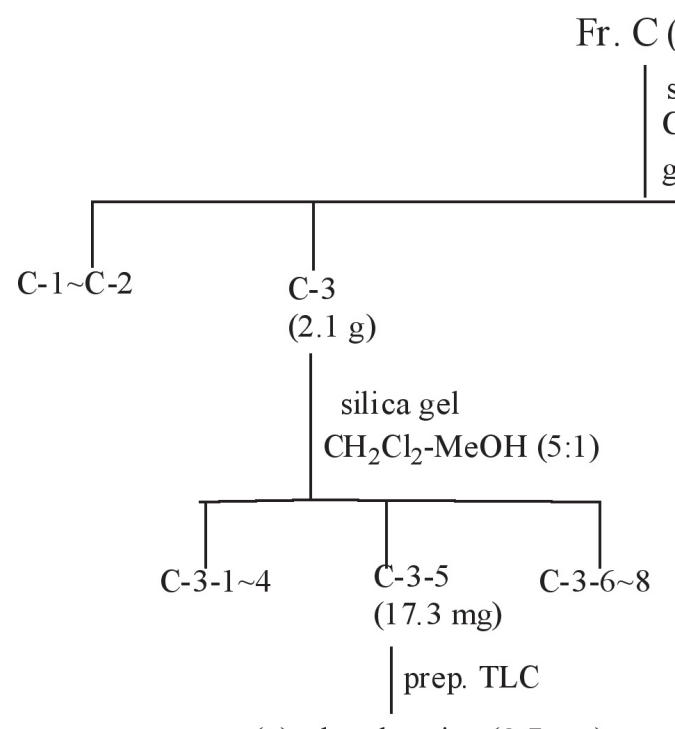

Fr. C $(14 \mathrm{~g})$

silica gel

$\mathrm{CH}_{2} \mathrm{Cl}_{2}-\mathrm{MeOH}$

gradient

(+)-platy des mine $(2.7 \mathrm{mg})$

(Sausuraceae), ${ }^{15}$ Fissistigma (Annonaceae), ${ }^{16}$ and Peperomia (Piperaceae) ${ }^{17}$ species. This type alkaloid possessed antiplatelet aggregation activity ${ }^{16}$ and cytotoxicity activity ${ }^{18}$ in previous reports.

The known compounds included five benzo[c]phenanthridines: decarine, ${ }^{19}$ norchelerythrine, ${ }^{19}$ oxynitidine, ${ }^{19}$ oxychelerythrine, ${ }^{19}$ and arnottianamide, ${ }^{19}$ five

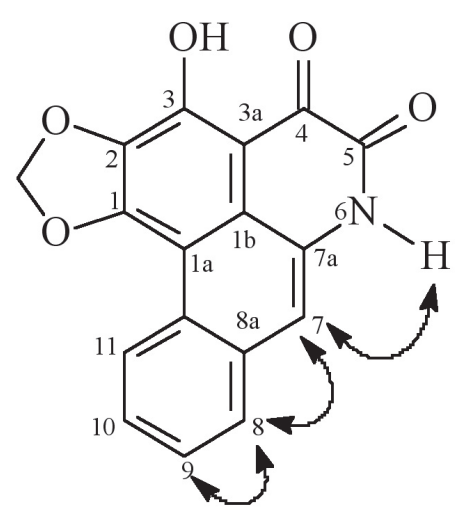

\section{Fig. 1. Key NOESY correlations $(7)$ of 1}

furoquinolines: dictamnine, ${ }^{20}$ skimmianine, ${ }^{20} \gamma$-fagarine, ${ }^{19}(+)$-platydesmine $;{ }^{19}$ and haplopine, ${ }^{20}$ five benzenoids: vanillin, ${ }^{21}$ methyl vanillate, ${ }^{21}$ vanillic acid ${ }^{22}$ tetracosyl ferulate, ${ }^{23}$ and 2-(4'-hydroxyphenyl)ethyl hexacosanoate ${ }^{24}$ one lignan: $(+)$-sesamin; ${ }^{25}$ two steroids: $\beta$-sitosterol, ${ }^{21}$ and stigmasterol:21 one terpenoid: lupeol. ${ }^{26}$ These compounds were identified by comparison of their spectral data (UV, IR, ${ }^{1} \mathrm{H}$ NMR, MS) with the data from the corresponding values in the literature, or with authentic samples. Among them, vanillin, oxychelerythrine, oxynitidine, tetracosyl ferulate, vanillic acid, methyl vanillate, 2-(4'-hydroxyphenyl)ethyl hexacosanoate, $(+)$-sesamin, $\beta$-sitosterol, and stigmasterol were isolated for the first time from this plant.

Zanthodione (1), methyl vanillate, vanillic acid, and 2-(4'hydroxyphenyl)ethyl hexacosanoate, cannot be afforded the anti-HIV screening in this study due to their small quantities and exhausted. The other 16 known compounds isolated in this study, also found in Z. ailanthoides, have been screened for anti-HIV activity in our previous study. ${ }^{9}$ Except for decarine, $\gamma$-fagarine and (+)-platydesmine, the other 12 compounds show no anti-HIV activity. From the results of the anti-HIV tests, the following conclusions can be drawn regarding these isolates: (a) The benzo[c]phenanthridine alkaloid, decarine, showed the highest anti-HIV activity in acutely infected H9 cells, with an $\mathrm{EC}_{50}$ value of $<0.1 \mu \mathrm{g} / \mathrm{mL}$. It inhibited uninfected $\mathrm{H} 9$ cell growth with an $\mathrm{IC}_{50}$ value of $22.6 \mu \mathrm{g} / \mathrm{mL}$, giving a calculated TI value of $>226 .{ }^{9}$ (b) In comparison with the inactive similar benzo[c]phenanthridine alkaloid, norchelerythrine, the $8-\mathrm{OH}$ group in benzo $[c]$ phenanthridine alkaloid seems to play an important role in the anti-HIV activity. The furoquinoline, $\gamma$-fagarine also showed a potent anti-HIV activity with $\mathrm{EC}_{50}$ and TI value of $<0.1 \mu \mathrm{g} / \mathrm{mL}$ and $>231$. In comparison, the other furoquinoline haplopine, which has a $7-$ $\mathrm{OH}$ in ring $\mathrm{A}$, showed decreased activity, while replacing the 7-OH with a 7- $-\mathrm{OCH}_{3}$ group and no substituents in ring A gave skimmianine and dictamnine, which showed no activity. We can conclude that the presence of the $8-\mathrm{OCH}_{3}$ group in furoquinoline may be essential for anti-HIV activity. Thus, among the above bioactive compounds, decarine, $\boldsymbol{\gamma}$-fagarine and $(+)$-platydesmine, also re-isolated in this study, can be proposed as anti-HIV constituents of the stem bark of $Z$. scandens. 
<smiles>[R]c1ccc2c(cnc3c4cc5c(cc4ccc23)OCO5)c1OC</smiles>

decarine $\mathrm{R}=\mathrm{OH}$ norchelerythrine $\mathrm{R}=\mathrm{OCH}_{3}$<smiles>CNc1c(-c2ccc(OC)c(OC)c2O)ccc2cc3c(cc12)OCO3</smiles>

arnottianamide<smiles>COc1c2c(nc3ccccc13)OC(C(C)(C)O)C2</smiles>

(+)-platy desmine<smiles>CCOC(=O)/C=C/c1ccc(O)c(OC)c1</smiles>

tetracosyl ferulate<smiles>c1cc2c(cc1[C@@H]1OC[C@H]3[C@H]1CO[C@H]3c1ccc3c(c1)OCO3)OCO2</smiles>

(+)-sesamin<smiles></smiles>

lupeol<smiles>[R]c1cc2c3ccc4cc5c(cc4n(C)c=3c(=O)c2c([R])c1OC)OCO5</smiles>

oxychelerythrine $\mathrm{R}_{1}=\mathrm{H}, \mathrm{R}_{2}=\mathrm{OCH}_{3}$ oxynitidine $\mathrm{R}_{1}=\mathrm{OCH}_{3}, \mathrm{R}_{2}=\mathrm{H}$<smiles>[R]c1ccc2c(OC)c3ccoc3nc2c1[R]</smiles>

dictamnine $\mathrm{R}_{1}=\mathrm{R}_{2}=\mathrm{H}$ skimmianine $\mathrm{R}_{1}=\mathrm{R}_{2}=\mathrm{OCH}_{3}$ $\gamma$-fagarine $\mathrm{R}_{1}=\mathrm{H}, \mathrm{R}_{2}=\mathrm{OCH}_{3}$ haplopine $\mathrm{R}_{1}=\mathrm{OH}, \mathrm{R}_{2}=\mathrm{OCH}_{3}$<smiles>[R]c1ccc(O)c(OC)c1</smiles>

vanill in $\mathrm{R}=\mathrm{CHO}$ methyl vanillate $\mathrm{R}=\mathrm{COOCH}_{3}$ vanillic acid $\mathrm{R}=\mathrm{COOH}$

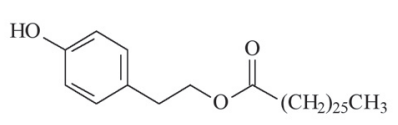

2-(4-hy droxyphenyl)ethyl hexacosanoate

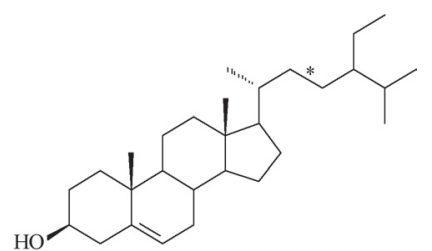

$\beta$-sitosterol stigmasterol $*=\triangle$

\section{ACKNOWLEDGEMENTS}

This work was kindly supported by the National Science Council of the Republic of China. (NSC 92-2320-B-037-019)

\section{REFERENCES}

1. C. E. Chang, T. G. Hartley, Rutaceae in Flora of Taiwan; 2nd edition, Editorial Committee of the Flora of Taiwan, Taipei, Taiwan, Vol. III, 1993; pp. 510-544.

2. Chung-Hua Ben Tsao. Shanghai Science and Technology Press, Shanghai, 1999; Vol. IV, 1999; p. 995.

3. H. R. Arthur, S. W. Tam, Y. L. Ng, J. Chem. Soc. 3551, (1961).

4. H. Ishii, T. Ishikawa, I. S. Chen, Tetrahedron Lett. 4189, (1973).

5. H. Ishii, T. Ishikawa, S. T. Lu, I. S. Chen, Yakugaku Zasshi 96, 1458, (1976).

6. G. Brader, G. Wurz, H. Greger, O. Hofer, Liebigs Ann. Chem. 355 , (1993).

7. H. R. Arthur, W. H. Hui, C. N. Ma, J. Chem. Soc. 632, (1956).

8. Q. A. Nguyen, H. T. Van-Dufat, S. Michel, F. Tillequin, V. Dumontet, T. Sevenet, J. Biosciences 57, 986, (2002).

9. M. J. Cheng, K. H. Lee, I. L. Tsai, I. S. Chen, Bioorg. Med. Chem. 13, 5915 (2005).

10. M. J. Cheng, C. F. Lin, C. J. Wang, I. L. Tsai, I. S. Chen, J. Chin. Chem. Soc. 54, 779, (2007).

11. D. Y. Si, S. X. Zhao, J. Z. Deng, J. Nat. Prod. 55, 828, (1992).

12. H. Achenbach, D. Frey, R. Waibel, J. Nat. Prod. 54, 1331, (1991).

13. S. K. Singh, A. K. Prasad, C. E. Olsen, A. Jha, S. C. Jain, V. S. Parmar, J. Wengel, Phytochemistry 43, 1355, (1996).

14. B. Achari, S. Chakrabarty, S. Bandyopadhyay, S. C. Pakarashi, Heterocycles 19, 1203, (1982).

15. A. Probstle, R. Bauer, Planta Med. 58, 568, (1992).

16. Y. C. Chia, F. R. Chang, C. M. Teng, Y. C. Wu, J. Nat. Prod. 63, 1160, (2000).

17. M. J. Cheng, S. J. Lee, Y. Y. Chang, S. H. Wu, I. L. Tsai, B. Jayaprakasam, I. S. Chen, Phytochemistry 63, 603, (2003).

18. M. A. Elban, J. C. Chapuis, M. Li, S. M. Hecht, Bioorg. Med. Chem. 15 , 6119 (2007).

19. M. J. Cheng, I. L. Tsai, I. S. Chen, J. Chin. Chem. Soc. 50, 1241, (2003).

20. M. J. Cheng, L. Tsai, I. S. Chen, J. Chin. Chem. Soc. 51, 1065, (2004).

21. C. Y. Chen, Y. C. Wu, J. Chin. Chem. Soc. 48, 1203, (2001).

22. Y. L. Lin, Y. H. Kuo, J. Chin. Chem. Soc. 42, 973, (1995).

23. K. S. Chen, F. R. Chang, Y. C. Chia, T. S. Wu, Y. C. Wu, J. Chin. Chem. Soc. 45, 103, (1998).

24. M. Aqui, W. Rahman, J. Chem. Soc. Perkin Trans. I, 1389, (1981).

25. S. L. Liu, I. L. Tsai, T. Ishikawa, T. Harayama, I. S. Chen, J. Chin. Chem. Soc. 47, 571, (2000).

26. K. C. Kao, Y. L. Ho, I. H. Lin, L. K. Ho, Y. S. Chang, J. Chin. Chem. Soc. 51, 199, (2004). 